\title{
Superior Thoracic Artery
}

National Cancer Institute

\section{Source}

National Cancer Institute. Superior Thoracic Artery. NCI Thesaurus. Code C33701.

An artery arising from the axillary artery that supplies the muscles of the superior chest. 